\title{
Clinical Significance of C-reactive protein in Pregnancy Induced Hypertension
}

\author{
Ayokunle Moses OLUMODEJI ${ }^{1^{*}}$, Olumide Emmanuel ADEWARA ${ }^{2}$, Olabisi Timothy \\ ADEYEMO $^{3}$, Segun Murtala GHAZALI ${ }^{4}$, Paul OLOWOYO ${ }^{5}$

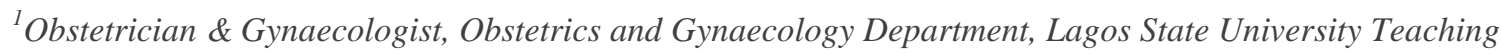 \\ Hospital, Lagos, Nigeria \\ ${ }^{2}$ Obstetrician \& Gynaecologist, Obstetrics \& Gynaecology Department, Federal Teaching Hospital, Ido-Ekiti, \\ Ekiti State, Nigeria. \\ ${ }^{3}$ Obstetrician \& Gynaecologist, Obstetrics \& Gynaecology Department, Federal Teaching Hospital, Ido-Ekiti, \\ Ekiti State, Nigeria \\ ${ }^{4}$ Head of Department, Chemical Pathology Department, Federal Teaching Hospital, Ido-Ekiti, Ekiti State, \\ Nigeria \\ ${ }^{5}$ Neurologist, Department of Internal Medicine, Federal Teaching Hospital, Ido-Ekiti, Ekiti State, Nigeria \\ *Corresponding Author: Ayokunle Moses OLUMODEJI, Obstetrician \& Gynaecologist, Obstetrics and \\ Gynaecology Department, Lagos State University Teaching Hospital, Lagos, Nigeria, \\ Email:ayokunleolumodeji@yahoo.com
}

\begin{abstract}
$C$ - reactive protein (CRP), a marker of inflammation from widespread endothelia injury in PIH may correlate with clinical measures. This study evaluated the association of maternal serum $C$-reactive concentration with clinical correlates in patients with pregnancy induced hypertension. This was a prospective study in which 44 patients with PIH and 88 controls that satisfied the inclusion criteria were recruited. A p-value $<0.05$ was considered significant.

The mean serum level of CRP was $29.7 \pm 17.1 \mu \mathrm{g} / \mathrm{ml}$ in women with PIH and $23.5 \pm 16.3 \mu \mathrm{g} / \mathrm{ml}$ in the normotensive group $((p=0.045)$; 95\% CI $(22.7-28.5))$. Mean serum levels of CRP in women with severe PIH $(32.2 \pm 16.4 \mu \mathrm{g} / \mathrm{ml})$ was significantly higher $(p=0.009)$ than in women with mild PIH $(22.2 \pm 17.7 \mu \mathrm{g} / \mathrm{ml})$. Babies born to mothers with PIH whose serum CRP levels were above the mean serum CRP had their mean $5^{\text {th }}$ minute Apgar score $(8.1 \pm 1.8)$ significantly lower than the mean $5^{\text {th }}$ minute Apgar score $(8.7 \pm 0.7)$ of babies born to mothers with PIH whose serum CRP levels were below the mean.
\end{abstract}

Serum CRP levels were elevated in women with pregnancy induced hypertension than in normotensive women and more elevated in severe PIH than in mild PIH. It showed reasonable positive correlation with disease severity and adverse fetal outcome that warrants further investigation.

Keywords: "Serum C-reactive Protein", "Pregnancy Induced Hypertension", "Preeclampsia”, "Pregnancy", "Fetal Outcome”, "C-reactive protein in pregnancy"

Abbreviations: BMI - Body Mass Index, BP - Blood Pressure, BW - Birth Weight, CI - Confidence Interval, $C R P-C$ - reactive protein, $f$ - Frequency, F - One-way Anova, IL - Illinois, Il - Interleukin, Inc Incorporated, NPV - Negative Predictive Value, $p$ - Statistical power, PIH - Pregnancy Induced Hypertension, PPV-Positive Predictive Value, ROC-Receiver Operating Characteristics, SCBU - Special Care Baby Unit, SPSS - Statistical Package for Social Sciences, $t$-Independent Samples t-test, USA - United States of America

\section{INTRODUCTION}

Pregnancy Induced Hypertension is hypertension with or without proteinuria emerging after 20 weeks gestation, but resolving not later than 12 weeks postpartum.[1]

ARC Journal of Gynecology and Obstetrics
Hypertensive disorders of pregnancy contributes significantly to morbidity and mortality in the fetus and mother both in the developed and developing countries with PIH listed as one of the top three causes of maternal mortality.[2] 
C-reactive protein is an acute phase serum protein. It is a surrogate for the proinflammatory interleukin IL-6 synthesized by liver. [3] It is also produced by cells in the vascular wall such as endothelial cells, smooth muscle cells, and also by adipose tissue.[3] CRP is known to be slightly elevated during pregnancy, due to the maternal inflammatory reaction to the pregnancy but this is further exaggerated in pre-eclampsia. An excessive maternal inflammatory response, perhaps directed against foreign fetal antigens, with widespread endothelia dysfunction, has been consistently demonstrated in pre-eclampsia. [4]

CRP rises within two hours of the onset of inflammation and its level is determined by the rate of production and hence the severity of the precipitating cause.[3] CRP is thus a screen for inflammation and may be of clinical relevance in pregnancy induced hypertension.

Given the significant impact of pregnancy induced hypertension on maternal and fetal well-being this study aimed to determine the association between maternal C-reactive protein and pregnancy induced hypertension compared with age- and parity- matched normotensive pregnant subjects.

\section{MATERIALS AND MeTHOdS}

This was a hospital-based, prospective study, carried out in the Department of Obstetrics and Gynaecology of the Federal Teaching Hospital, Ido-Ekiti, Ekiti State, Nigeria. Forty four cases of women with pregnancy induced hypertension were matched with 88 controls of normotensive women. Serum levels of C-reactive protein in women with pregnancy induced hypertension were compared with those of healthy normotensive pregnant women. Matching of both groups were done in age, parity and gestational ages and timing at diagnosis. The recruitment and follow-up process lasted for a period of ten months ( $1^{\text {st }}$ August, $2016-31^{\text {st }}$ May 2017). The patients were adequately counselled about the study and thereafter an informed consent was obtained before they were recruited into the study. Cases were recruited by convenience sampling technique while controls were recruited using systematic random sampling.

\section{Participants}

The study population consisted of singleton pregnant women between 20 and 42 weeks of gestation or in labour with pregnancy induced hypertension. Patients suspected or confirmed with any of the following conditions associated with elevated or reduced C-reactive protein such as: acute or chronic inflammatory conditions, tissue necrosis or tissue injury, infection or inflammation, premature rupture of membranes, metabolic syndrome, malignant tumors, acute pancreatitis, burns, leukemia, tobacco smoking, alcohol consumption were excluded from the study.[5]

\section{Procedure}

A structured proforma was used to obtain relevant data from each patient. Data obtained from the subjects and controls included age, tribe, educational status, occupation, parity, gestational age and history of hypertension, renal disease and history of PIH in previous pregnancies. The severity and type of pregnancy induced hypertension was noted in the subjects. The result of the serum C-reactive concentrations determined from the samples of the subjects and control taken at the time of diagnosis was equally recorded on the proforma.The estimated gestational age at diagnosis in the subjects were matched with controls using a matching factor of + or 1 week.The mean serum C-reactive protein at diagnosis of pregnancy induced hypertension were compared in cases and controls and their possible correlation with the disease severity and fetal outcome. Subjects recruited during the antenatal period were followed up till delivery with their matched controls. Subjects recruited in labour were matched with controls in labour. Severe PIH in the study was defined as a systolic blood pressure of $160 \mathrm{mmHg}$ and/or diastolic blood pressure of $90 \mathrm{mmHg}$.[6]

The birth weight of each baby was determined within 30 minutes of delivery. The Apgar scores in the first and fifth minutes of life were determined using the Apgar scale devised by Virginia Apgar in 1952.

Five milliliters $(5 \mathrm{mls})$ of venous blood was drawn from the forearm vein of the selected patients under aseptic condition, collected in a non-heparinized specimen bottle and allowed to clot spontaneously and the serum separated after centrifugation at $3000 \mathrm{rpm}$ for 15 minutes. The samples were then refrigerated at $2-8^{\circ} \mathrm{C}$ until spectrophotometric analysis.

The data and information obtained from the study were processed using statistical package for social sciences version 20 (SPSS Inc., Chicago, Illinois, USA). Frequency tables were generated and the results tested for statistical 
significance using odds ratio, chi-square and student t-test where appropriate. Tests of association were determined using logistic regression models. The receiver operating 5. RESUlts

Table1. Mean parameters of the study participants

\begin{tabular}{|c|c|c|c|c|c|}
\hline \multirow{2}{*}{ Variables } & Women with PIH & Women without PIH & \multirow{2}{*}{$\mathbf{T}$} & \multirow{2}{*}{$95 \%(C I)$} & \multirow[b]{2}{*}{$P$ value } \\
\hline & $\mathrm{n}=44(\%)$ & $\mathrm{n}=88(\%)$ & & & \\
\hline Mean Age (years) & $28.7 \pm 6.1$ & $29.6 \pm 4.2$ & 0.991 & $26.8-30.6$ & 0.323 \\
\hline Mean Parity & $1.1 \pm 1.1$ & $1.27 \pm 1.1$ & 0.802 & $1.0-1.5$ & 0.423 \\
\hline Mean Gestational age (weeks) & $37.8 \pm 2.4$ & $39.0 \pm 1.7$ & 3.145 & $38.2-39.0$ & 0.002 \\
\hline Mean BMI $\left(\mathrm{kg} / \mathrm{m}^{2}\right)$ & $29.2 \pm 4.9$ & $29.0 \pm 4.6$ & 0.172 & $28.1-30.0$ & 0.863 \\
\hline Mean Systolic BP (mmHg) & $166.0 \pm 18.1$ & $112 \pm 11.2$ & 20.84 & $125.5-135.4$ & $<0.001$ \\
\hline Mean Diastolic BP (mmHg) & $105.9 \pm 13.0$ & $69.0 \pm 9.2$ & 18.82 & $77.7-84.8$ & $<0.001$ \\
\hline Mean APGAR at 1 minute & $6.7 \pm 1.8$ & $7.6 \pm 1.2$ & 3.486 & $7.1-7.6$ & $<0.001$ \\
\hline Mean APGAR at 5 minutes & $8.4 \pm 1.5$ & $8.9 \pm 1.1$ & 2.374 & $8.5-9.0$ & 0.019 \\
\hline Mean Birth weight $(\mathrm{kg})$ & $2.7 \pm 0.6$ & $3.2 \pm 0.4$ & 6.692 & $3.0-3.1$ & $<0.001$ \\
\hline
\end{tabular}

t- Independent samples t-test, PIH-Pregnancy Induced Hypertension

Table2. Mean serum CRP in women with and without PIH

\begin{tabular}{|c|c|c|c|c|c|}
\hline \multirow{2}{*}{ Variables } & With PIH & Without PIH & \multirow[b]{2}{*}{$\mathbf{T}$} & \multirow{2}{*}{$95 \%$ (CI) } & \multirow{2}{*}{$P$ value } \\
\hline & $n=44(\%)$ & $\mathrm{n}=\mathbf{8 8}(\%)$ & & & \\
\hline $\mathrm{CRP}(\mu \mathrm{g} / \mathrm{ml})$ & $29.7 \pm 17.1$ & $23.5 \pm 16.3$ & 2.021 & $22.7-28.5$ & 0.045 \\
\hline
\end{tabular}

t- Independent samples t-test

Table3. Mean serum level of CRP and Severity of PIH

\begin{tabular}{|l|c|c|c|c|c|}
\hline \multirow{2}{*}{ Variables } & Mild PIH & Severe PIH & \multirow{2}{*}{ t } & \multirow{2}{*}{ 95\% (CI) } & P value \\
\cline { 2 - 3 } & $\mathbf{n = 1 1}$ & $\mathbf{n = 3 3}$ & & & 0.009 \\
\hline $\mathrm{CRP}(\mu \mathrm{g} / \mathrm{ml})$ & $22.2 \pm 17.7$ & $32.2 \pm 16.4$ & 1.707 & $24.0-34.9$ & \\
\hline
\end{tabular}

$t$ - Independent samples $t$-test

Table4. Comparison of Mean Serum CRP levels based on type of PIH

\begin{tabular}{|c|c|c|c|c|c|c|}
\hline \multirow{3}{*}{ Variable } & \multirow[b]{2}{*}{$\begin{array}{c}\text { Gestational } \\
\text { Hypertension n } \\
=17\end{array}$} & \multicolumn{3}{|c|}{ Types of PIH } & & \\
\hline & & $\begin{array}{c}\text { Pre-Eclampsia } \\
n=18\end{array}$ & $\begin{array}{c}\text { HTN + } \\
\text { Superimposed Pre- } \\
\text { Eclampsia } \\
\text { n=3 }\end{array}$ & $\begin{array}{l}\text { Eclampsia } \\
\quad n=6\end{array}$ & \multicolumn{2}{|c|}{ Statistical test } \\
\hline & Mean \pm SD & Mean \pm SD & Mean \pm SD & Mean \pm SD & $\mathrm{F}$ & $\mathrm{p}-$ value \\
\hline CRP & $18.8 \pm 14.9$ & $33.6 \pm 15.1$ & $30.5 \pm 19.1$ & $48.6 \pm 2.3$ & 7.18 & $<0.001$ \\
\hline
\end{tabular}

F-One - way ANOVA

Table5. Serum CRP as a predictor of severe PIH

\begin{tabular}{|l|l|l|l|}
\hline \multicolumn{1}{|c|}{ Contingency table } & \multicolumn{1}{|c|}{$\begin{array}{c}\text { Mild PIH } \\
\mathbf{f}(\boldsymbol{\%})\end{array}$} & \multicolumn{1}{|c|}{$\begin{array}{c}\text { Severe PIH } \\
\mathbf{f}(\boldsymbol{\%})\end{array}$} & \multicolumn{1}{c|}{ Total } \\
\hline$\geq$ Mean CRP & $4(16)$ & $21(84)$ & $25(100)$ \\
\hline$<$ Mean CRP & $7(36.8)$ & $12(63.2)$ & $19(100)$ \\
\hline Total & $11(25)$ & $33(75)$ & $44(100)$ \\
\hline
\end{tabular}

$f$-Frequency,

$\%$ - row percentage

Table6. Foetal outcomes and serum level of CRP among PIH group

\begin{tabular}{|l|l|l|l|l|}
\hline \multirow{2}{*}{ Foetal outcomes } & \multicolumn{2}{|c|}{ Serum levels of CRP $(\boldsymbol{\mu g} / \mathbf{m l})$} & \multirow{2}{*}{ P value } \\
\cline { 2 - 4 } & $\begin{array}{c}<\text { mean level } \\
(\mathbf{n = 1 9})\end{array}$ & $\begin{array}{c}\text { >mean level } \\
(\mathbf{n = 2 5})\end{array}$ & \multirow{2}{*}{ T } & \\
\hline APGAR & $8.7 \pm 0.7$ & $8.1 \pm 1.8$ & 1.378 & 0.047 \\
\hline Birth weight & $2.8 \pm 0.5$ & $2.5 \pm 0.6$ & 1.443 & 0.156 \\
\hline
\end{tabular}

t- Independent samples $t$-test

ARC Journal of Gynecology and Obstetrics 
Table7. Foetal outcomes and serum level of CRP among PIH group

\begin{tabular}{|c|c|c|c|}
\hline \multirow[b]{2}{*}{ Foetal outcomes } & \multicolumn{2}{|c|}{ serum level of CRP $(\mu \mathrm{g} / \mathrm{ml})$} & \multirow[b]{2}{*}{$P$ value } \\
\hline & $\begin{array}{c}\text { mean level } \\
n=19(\%)\end{array}$ & $\begin{array}{c}\text { >mean level } \\
n=25(\%)\end{array}$ & \\
\hline \multicolumn{4}{|l|}{ Birth Status } \\
\hline Live birth & $19(44.2)$ & $24(55.8)$ & $0.568^{*}$ \\
\hline Stillbirth & $0(0.0)$ & $1(100.0)$ & \\
\hline \multicolumn{4}{|l|}{ Admission into SCBU } \\
\hline Yes & $4(28.6)$ & $10(71.4)$ & $0.156^{*}$ \\
\hline No & $15(50.0)$ & $15(50.0)$ & \\
\hline
\end{tabular}

*Fishers exact test

Table8. Bivariate correlation of CRP and BW and Apgar score

\begin{tabular}{|l|l|l|l|l|}
\hline \multicolumn{2}{|l|}{ PIH Group } & Control Group \\
\hline & CRP (Coeff.) & p - value & CRP (Coeff.) & p - value \\
\hline Birth Weight & -0.40 & $0.014^{* *}$ & -0.03 & $0.716^{* *}$ \\
\hline APGAR at 5 mins & -0.31 & $0.060^{* *}$ & -0.07 & $0.489^{* *}$ \\
\hline
\end{tabular}

**Spearman's rank correlation

Table9. Regression analysis for serum level of CRP

\begin{tabular}{|c|c|c|c|}
\hline \multirow[t]{2}{*}{ Variables } & \multicolumn{2}{|r|}{ CRP $\mu \mathrm{g} / \mathrm{ml}$} & \multirow[b]{2}{*}{$P$ value } \\
\hline & & \begin{tabular}{l|l} 
& $95 \% \mathrm{CI}$
\end{tabular} & \\
\hline Gravidity & -3.29 & $-6.7-0.15$ & 0.006 \\
\hline BMI & 0.25 & $-0.91-1.41$ & 0.062 \\
\hline Previous PIH & -1.35 & $-13.7-11.0$ & 0.825 \\
\hline APGAR@5min & -3.91 & $-0.82-2.28$ & 0.032 \\
\hline SCBU & -1.74 & $-0.91-3.33$ & 0.093 \\
\hline Birth Weight & -1.24 & $-0.23-3.72$ & 0.049 \\
\hline
\end{tabular}

\section{DISCUSSION}

The mean serum level of CRP in women with PIH $(29.7 \pm 17.1 \mu \mathrm{g} / \mathrm{ml})$ was significantly higher than in normotensive controls $(23.5 \pm 16.3 \mu \mathrm{g} / \mathrm{ml})$ (Table 2). Onuegbu et al and Oyeyemi et al in Nigeria and TK Ghosh et al in India noted a similar finding of significantly higher mean serum CRP in PIH cases compared with controls. $[7,8,9]$ However, serum CRP levels in this study were relatively higher than levels reported by Onuegbu et al $(8.57 \pm 2.68 \mathrm{mg} / \mathrm{l})$ and Oyeyemi et al $(3.01 \pm 1.40 \mathrm{mg} / \mathrm{l})$ but lower than serum CRP values reported by TK Ghosh et al $(42.02 \pm 18.01 \mathrm{mg} / \mathrm{L}) \cdot[7,8,9]$ Women were recruited in the ante-partum and intra-partum period and this may explain the relatively higher mean CRP in this study compare to Onuegbu et al and Oyeyemi et al whose studies were limited to the ante-partum period.

Furthermore, women with severe PIH had significantly higher $(\mathrm{p}=0.009)$ mean serum CRP values compare to women with mild PIH (Table $3)$. This agrees with records of studies by Ertas et al[10] in Ankara, Turkey and Hwang et al,[11] providing further support to the hypothesis that pre-eclampsia is associated with systemic inflammation from widespread endothelia injury.

The serum concentration of CRP varied with the type of pregnancy induced hypertension (Table 4). Women with Gestational hypertension had the least mean serum CRP followed by women with chronic hypertension with superimposed preeclampsia and women withpreeclampsia. Eclamptics in this study had the highest mean serum concentration of CRP $(48.6 \pm 2.3 \mu \mathrm{g} / \mathrm{ml})$. Serum CRP was significantly higher in preeclampsia and eclampsia than gestational hypertension (Table 4). Higher serum CRP levels were noted in pre-eclamptics and eclamptics than in women with gestational hypertension by Ertas et al.[10] This classification mirrors disease pathophysiology, progression and severity, the relatively high levels of serum CRP in pre-eclamptics and eclamptics in this study may suggest the possible use of CRP as markers of severity in PIH.[12]

This study revealed a sensitivity and specificity of $63.6 \%$ for serum CRP as a predictor of severe $\mathrm{PIH}$, using the mean serum CRP of $29.7 \mu \mathrm{g} / \mathrm{ml}$ as a cut-off (Table 5). Gandevani et al [13] in a study in north Iran, using serum CRP of 
$50 \mu \mathrm{g} / \mathrm{ml}$ as cut-off predicted severe preeclampsia with sensitivity of $93.9 \%$ and specificity of $75.7 \%$. While, Ertas in Turkey, using $9.66 \mathrm{mg} / \mathrm{L}$ as cut-off to evaluate disease severity in PIH, noted $88 \%$ sensitivity, $81 \%$ specificity, $71 \%$ positive predictive value and 92\% negative predictive value.[10] These results differed from findings in this study probably because cut-off points used varied in both study.

Babies born to mothers with PIH whose serum CRP levels were above the mean serum CRP had their 5th minute Apgar score $(8.1 \pm 1.8)$ significantly lower than 5th minute Apgar score $(8.7 \pm 0.7)$ of babies born to mothers with PIH whose serum CRP levels were below the mean serum CRP level ( $\mathrm{p}=0.047$, Table 6).

These significant findings of relatively poorer fetal outcome in women with serum CRP above mean values suggests the likelihood of threshold serum levels, above which, correlates with severe disease and adverse fetal outcome in $\mathrm{PIH}$. This further strengthens the possible role of CRP as potential markers of severity in PIH as suggested by other studies.[7,14]

Multiple linear regression analysis showed that serum CRP increased as birth weights reduced (Table 9). Serum CRP had significant association with Apgar scores and parity when adjusted for other variables. Ernst et al in a cohort study in Rotterdam, Netherlands after adjusting models for maternal BMI found that elevated CRP levels were still associated with fetal growth restriction and increased risks of LBW.[15] Similar finding was reported by Sharmin et al in Bangladesh.[16] These results indicate that elevated CRP levels, as a marker of maternal inflammation, are associated with fetal growth restriction.

Serum CRP showed inverse correlation with baby's birth weight and Apgar score at 5 minutes among women with PIH (Table 9). The inverse correlation of serum CRP with birth weight agrees with findings by Sharmin et al.[16] These findings suggest that elevated serum CRP is a biomarker that can be investigated to identify women with $\mathrm{PIH}$ at increased risk of severe disease and adverse fetal outcomes.

\section{REFERENCES}

[1] Janga D. Pregnancy induced hypertension a complication of pregnancy. Obs and gynae today. 2005;X(7):395-8.

[2] KuklinaEV, Ayala C, Callaghan WM. Hypertensive disorders and severe obstetric morbidity in the United States. Obstet Gynecol. 2009;113(6):1299-306.

[3] McPherson RA, Matthew R, PincusMR. Henry's Clinical Diagnosis and Management by Laboratory Methods. 22nd ed. Philadelphia: Elsevier Saunders; 2011. p. 254-5.

[4] Nwosu Z, Omabe M. Maternal and Foetal Consequences of Pre-eclampsia. The Internet Journal of Obstetrics and Gynaecology. 2009; 13:1.

[5] Burris CA, Ash wood ER, Burns DE, editor. Tietz Textbook of Clinical Chemistry and Molecular Diagnostics. 4th ed. St. Louis: Elsevier Saunders; 1633.

[6] AwrlnRL, Iwuala NC, Odum CU, Aust NZ. Pre-eclampsia at Lagos University Teaching Hospital. J ObstetGynaecol. Aug 2005;45(4):278-82.

[7] Ghosh TK, Ghosh S, Bhattacharjee D. Creactive protein levels in women with pregnancy induced hypertension. Bangladesh Journal of Medical Science. 2011;10(3):159-62.

[8] OnuegbuAJ, OlisekodiakaJM, UdoJU, Umeononihu O, Amah UK, Okwara JE, et al. Evaluation of High-Sensitivity C-Reactive Protein and Serum Lipid Profile in Southeastern Nigerian Women with PreEclampsia. Medical Principles and Practice. 2015;24(3):276-9.

[9] Oyeyemi A, Asaolu M. F. Evaluation of some Marker Enzymes, Prostaglandins, C-Reactive Protein and Plasma Total Protein, in Pregnancy Induced Hypertension among women in Ekiti State, Nigeria Journal of Biology, Agriculture and Healthcare. 2015;5:170-6.

[10] Ertas IE, Kahyaoglu S, Yilmaz B, Ozel M, Sut $\mathrm{N}$, Guven MA, et al. Association of maternal serum high sensitive C-reactive protein level with body mass index and severity of preeclampsia at third trimester. J ObstetGynaecol Res. 2010;36(5):970-7.

[11] Hwang HS, Kwon JY, Kim MA, Park YW, Kim YH. Maternal serum highly sensitive Creactive protein in normal pregnancy and preeclampsia. International journal of gynaecology and obstetrics: the official organ of the International Federation of Gynaecology and Obstetrics. Aug 2007;98(2):105-9.

[12] Evrüke IC, Demir SC, Urünsak IF, Ozgünen FT, Kadayifçi O. Comparison of lipid profiles in normal and hypertensive pregnant women. Ann Saudi Med. 2004;24(5):382-85.

[13] Gandevani SB, Banaem LM, Mohamadi B, Moghadam NA, Asghari M. Association of high-sensitivity $\mathrm{C}$-reactive protein serum levels in early pregnancy with the severity of preeclampsia and fetal birth weight. Journal of perinatal medicine. 2012;40(6):601-5. 
[14] Paternoster DM, Fantinato S, Stella A, Nanhorngue KN, Milani M, Plebani M, et al. C-reactive protein in hypertensive disorders in pregnancy. Clinical and applied thrombosis/hemostasis: official journal of the International Academy of Clinical and Applied Thrombosis/Hemostasis. 2006;12(3):330-7.

[15] Ernst GDS, de Jonge LL, Hofman A, Lindemans J, Russcher H, SteegersEAP, et al. C-reactive protein levels in early pregnancy, fetal growth patterns, and the risk for neonatal complications: the Generation $\mathrm{R}$ Study. American Journal of Obstetrics and Gynecology. 2011;205(2):132.e1-.e12.

[16] Sharmin S, Chy S, Alam D, Banu N, Rashid F, Kabir S. Association of Serum C-reactive Protein in Preeclampsia and its Effect on Fetal Birth Weight - A Case Control Study. 2017. 2017;31(2):6.

Citation: Ayokunle Moses OLUMODEJI, Olumide Emmanuel ADEWARA, Olabisi Timothy ADEYEMO, Segun Murtala GHAZALI, Paul OLOWOYO. Clinical Significance of C-reactive protein in Pregnancy Induced Hypertension. ARC Journal of Gynecology and Obstetrics. 2019; 4(2):9-14. DOI:dx.doi.org/10.20431/24560561.0402002.

Copyright: () 2019 Authors. This is an open-access article distributed under the terms of the Creative Commons Attribution License, which permits unrestricted use, distribution, and reproduction in any medium, provided the original author and source are credited. 